\title{
Article
}

\section{Mineral extinction}

\author{
Stuart J. Mills ${ }^{1 *}$ and Andrew G. Christy 2,3 \\ ${ }^{1}$ Geosciences, Museums Victoria, GPO Box 666, Melbourne, Victoria 3001, Australia; ${ }^{2}$ Geosciences, The Queensland Museum, 122 Gerler Road, Hendra, Queensland \\ 4011, Australia; and ${ }^{3}$ School of Earth and Environmental Sciences, The University of Queensland, St Lucia, Queensland 4072, Australia.
}

\begin{abstract}
'Mineral evolution' has attracted much attention in the last decade as a counterpart of the long-established biological concept, but is there a corresponding 'mineral extinction'? We present new geochronological data from uranium-bearing secondary minerals and show that they are relatively recent, irrespective of the age of their primary uranium sources. The secondary species that make up much of the diversity of minerals appear to be ephemeral, and many may have vanished from the geological record without trace. Nevertheless, an 'extinct' mineral species can recur when physiochemical conditions are appropriate. This reversibility of 'extinction' highlights the limitations of the 'evolution' analogy. Mineral occurrence may be time-dependent but does not show the unique contingency between precursor and successor species that is characteristic of biological evolution.
\end{abstract}

Keywords: mineral evolution, U-Th dating, mineralogy, extinction, mineral ecology, secondary mineral, Archaean

(Received 18 July 2019; accepted 12 September 2019; Accepted Manuscript published online: 20 September 2019; Associate Editor: Daniel Atencio)

\section{Introduction}

Over the last decade, parallels have been drawn between wellestablished aspects of evolution and diversity in the biological world and the increase in diversity and complexity of mineral species through the past 4.5 billion years of Earth history. This similarity launched the concept of 'mineral evolution', which was initially mooted by Zhabin (1979) and then by Hazen et al. (2008). It was subsequently expanded upon in papers such as: Hazen et al. (2014), Grew et al. (2016), Krivovichev et al. (2017) and Grew et al. (2019), along with the related idea of 'mineral ecology' (Hazen et al., 2015). The generalisation of evolutionary phenomena to non-biological complex systems was discussed in general terms by Hazen and Eldredge (2010). The concept of evolution through geological time in mineralogy has had a significant impact on communication of the science and now underpins displays in major museums such as 'Die Evolution der Minerale' gallery at the Naturhistorisches Museum in Vienna, Austria (Koeberl et al., 2018) and The Mignone Halls of Gems and Minerals at the American Museum of Natural History (AMNH, 2017). However, the analogy should be applied with caution, given the fundamental difference in underlying 'evolutionary' principles. The analogy arises in part because the living and nonliving spheres have interacted and co-evolved (Stewart, 2014). However, we raise the question of how far it can be applied: in particular, whether 'extinction' of minerals occurs as it does in biologic systems.

The biological world shows a broad pattern of increasing functional and structural complexity through time, which is shared by minerals despite the absence of genetically-based phylogeny.

\footnotetext{
*Author for correspondence: Stuart J. Mills, Email: smills@museum.vic.gov.au Cite this article: Mills S.J. and Christy A.G. (2019) Mineral extinction. Mineralogical Magazine 83, 621-625. https://doi.org/10.1180/mgm.2019.60

Organisms can die out, leaving no progeny, although structurally and functionally convergent species can arise to fill similar ecological niches in other places and times through selection pressures. The explosion in the complexity of life seems more subdued once it is acknowledged that $99.9 \%$ of biological species are extinct rather than extant (Raup, 1986; Newman, 1997). The secular diversification of the mineral world may also be modulated by analogous 'mineral extinction'. We have studied the geochronology of some 'secondary' uranium minerals derived by alteration of 'primary' uranium source minerals of known age, and found the results to have important implications for the nature of 'mineral extinction'. The rationale, methods and results of this work are presented and discussed below.

\section{Experimental rationale}

The majority of the $c a .5500$ known mineral species formed near the Earth's surface, at pressures and temperatures close to ambient relative to the full range of geologically possible conditions. They may form as primary precipitates from liquids and condensates from gases, or through alteration or replacement of other solid phases. In particular, Hazen et al. (2008) noted that more than half of known species are hydrated and/or oxidised products formed by reaction of earlier minerals with oxygenated water and that this proportion is even higher for some chemical subclasses: $\sim 80 \%$ in the case of uranium minerals. Thus, any count of mineral species at a particular locality or for a particular constituent element is likely to be dominated by such secondary species, and it is meaningful to make a distinction between these and the 'primary' minerals whose formation did not involve extensive interaction with the atmosphere and hydrosphere.

For the purposes of the present study, we define 'secondary' parageneses to be those where minerals have crystallised after at least partial dissolution of precursors under near-surface 
conditions by fluids with a substantial meteoric-water component. This is consistent with the idea that such minerals tend to be oxidised, as rain and groundwater are sources of oxygen under modern atmospheric conditions. The depths that such fluids can reach thus determine the possible range of pressuretemperature conditions for such secondary mineralisation. The deepest aquifer on Earth, the Great Artesian Basin of Australia, carries meteoric-sourced water down to a depth of $3 \mathrm{~km}(300$ bars lithostatic pressure, close to that of the critical point for water). At a typical geothermal gradient of $25^{\circ} \mathrm{C} / \mathrm{km}$, this depth corresponds to a temperature of $100^{\circ} \mathrm{C}$, but is very far below the boiling point of pure water at that pressure.

Tectonic and atmospheric conditions on Earth have changed through geological time, and it has become evident that this exerts a profound effect on the numbers and abundances of mineral species that have been able to form in different geological periods. This time-dependence has been termed 'mineral evolution'. The paper by Hazen et al. (2008) defined ten mineral-evolutionary stages in the history of the Earth, which correspond to pauses between pulses in the rate of appearance of new mineral species, and can be correlated with changes in the behaviour of the lithosphere, hydrosphere, atmosphere and biosphere. A subsequent series of papers examined this evolutionary behaviour in more detail for minerals of specific chemical elements (e.g. Hazen et al., 2009, 2012; Grew et al., 2016). The change in mineralogical makeup of the crust has controlled age distributions of metallogenesis for various elements (Hazen et al., 2014) and has been associated intimately with biological activity ('coevolution of life and minerals') since the Archaean, as shown by the occurrence of stromatolites at 3.5 Ga (Vasconcelos and McKenzie, 2009). There has also been a consistent trend towards mineral species showing a greater range of chemical and structural complexity through time (Krivovichev et al., 2017). One methodological limitation for this type of study is that geochronological data for localities is limited, and data for one mineral of an element have been assumed to apply for all associated minerals of that element, irrespective of their primary or secondary nature. This is immaterial if the secondary species formed relatively soon after the primary minerals and have been preserved with them, but otherwise may overestimate the age of the first appearance for the secondary species, as acknowledged by Hazen et al. (2012). The study of boron mineral evolution by Grew et al. (2016) showed that the cumulative increase in species and complexity remains in that case, even when blatantly ephemeral recent products are removed from the database for each locality.

Uranium minerals are particularly amenable to geological dating from very small samples, as the predominant isotope ${ }^{238} \mathrm{U}$ is a major constituent of the total $U$ content (97.3 at.\%) and radioactive with a half-life comparable to the age of the Earth. Today, uranium occurs in multiple valence states: as relatively immobile $\mathrm{U}^{4+}$ in a small number of very insoluble primary minerals, such as uraninite (ideally $\mathrm{UO}_{2}$ ); as $\mathrm{U}^{6+}$ in a much larger number of species containing the relatively mobile, soluble uranyl cation $\left[\mathrm{UO}_{2}\right]^{2+}$, such as torbernite and francevillite (Fig. 1); and rarely as the intermediate $\mathrm{U}^{5+}$ in minerals such as wyartite. The enhanced mobility and ability to form a wide range of mineral structures leads to the great diversity of $\mathrm{U}^{6+}$ minerals under nearsurface conditions (Burns et al., 1997; Lussier et al., 2016). Thus, uranium mineral diversity has evolved markedly through geological time (Hazen et al., 2009), from the anoxic conditions of the Archaean, dominated by primary and detrital deposits of $\mathrm{U}^{4+}$ minerals, through to the present day, when such deposits

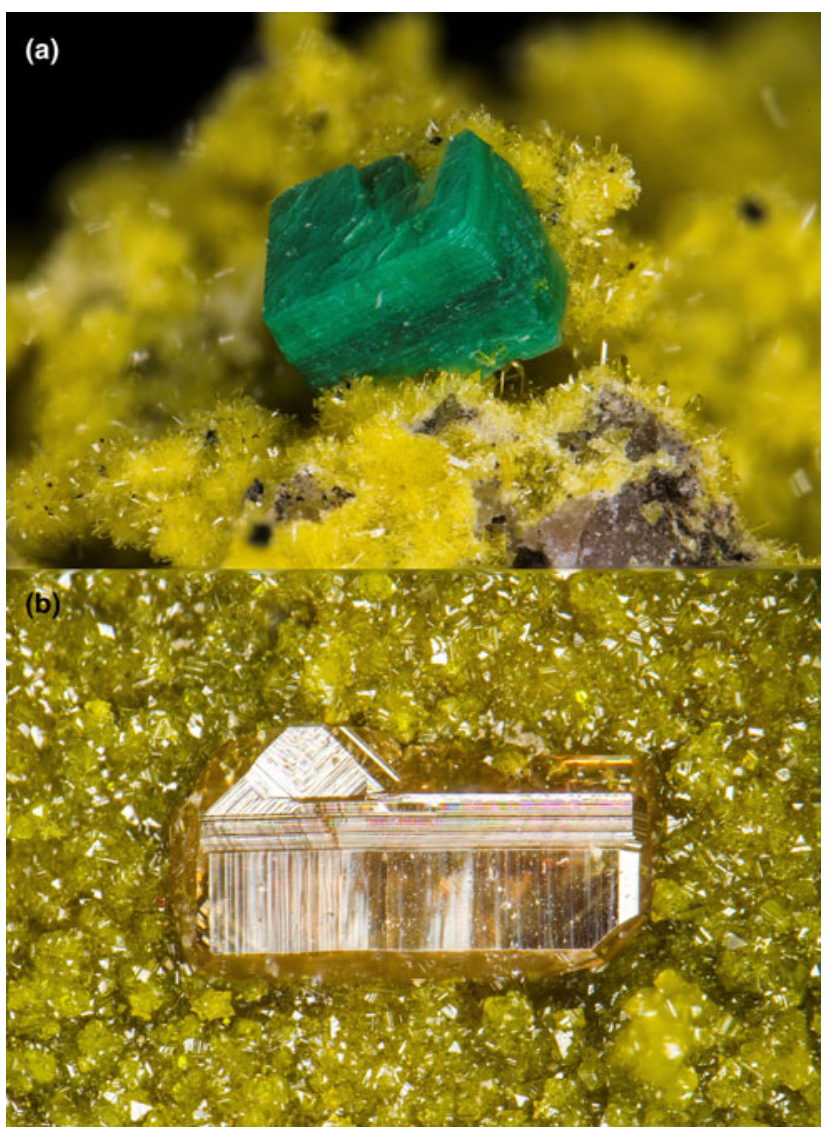

Fig. 1. (a) Torbernite on kasolite from Shinkolobwe, DRC; (b) chervetite on francevillite from Mounana mine, Gabon. Field of view $\sim 2.5 \mathrm{~mm}$ across. Collection Valérie Galea-Clolus.

oxidise readily to produce a profusion of $\mathrm{U}^{6+}$ secondary species. Oxidation also produces dissolved $\left[\mathrm{UO}_{2}\right]^{2+}$, which in turn can be transported and reduced again through contact with organic matter to produce tertiary $\mathrm{U}^{4+}$ deposits such as those impregnating sandstones of the Colorado Plateau.

Hazen et al. (2009) note that some $\mathrm{U}^{6+}$ would have formed through radiation-induced auto-oxidation even in the anoxic Archaean, and that formation of hydrothermal uraninite by reduction from uranyl-bearing fluids became important after the Great Oxidation Event of $\sim 2.2 \mathrm{Ga}$ ago, as evidenced by divergence in the geochemical behaviour of $U$ from that of Th, which does not have a mobile hexavalent state. Their deduction that most uranyl minerals only appeared after the Great Oxidation Event seems entirely reasonable. However, ages determined directly from secondary uranyl minerals are scarce in the literature. In this study, we present geochronological data for secondary $U$ minerals from deposits with a wide range of overall age and show that in all cases the secondary minerals are of recent origin, irrespective of the age of the primary $U$ source.

\section{Methods}

Single crystals were handpicked from specimens in the geological collections of Museums Victoria, Australia (Table 1). The crystals or fragments were weighed into Savillex PFA beakers and dissolved in $1 \mathrm{ml}$ of $7 \mathrm{M} \mathrm{HNO}_{3}$ for 3 days $\left(100^{\circ} \mathrm{C}\right.$, capped beaker). On the basis of preliminary tests which indicated high to very 
Table 1. U-Th dating samples from a variety of worldwide deposits.

\begin{tabular}{|c|c|c|c|c|c|c|}
\hline Museum no. & Mineral name* & 'Age' (ka) & Error $(k a, 2 \sigma)$ & Locality ${ }^{\star \star}$ & Deposit age & Ref. \\
\hline M37839 & sklodowskite & 315.6 & 21.5 & Eva mine, Northern Territory, Australia & $\sim 900 \mathrm{Ma}$ & {$[1]$} \\
\hline M36227 & parsonsite & 240.9 & 10.1 & Ranger U mine, Northern Territory, Australia & $\sim 1720$ to $\sim 1680 \mathrm{Ma}$ & {$[1]$} \\
\hline M45674 & saléeite & 21.7 & 0.3 & Ranger U mine, Northern Territory, Australia & $\sim 1720$ to $\sim 1680 \mathrm{Ma}$ & {$[1]$} \\
\hline M44969 & dewindtite & 349.1 & 30.6 & Ranger U mine, Northern Territory, Australia & $\sim 1720$ to $\sim 1680 \mathrm{Ma}$ & {$[1]$} \\
\hline M43448 & francevillite & 239.5 & 7.0 & Sleisbeck U mine, Northen Territory, Australia & $\sim 900 \mathrm{Ma}$ & {$[1]$} \\
\hline M37677 & tyuyamunite & 239.9 & 11.3 & Musonoi mine, Shaba, DRC & 560 to $500 \mathrm{Ma}$ & {$[2]$} \\
\hline M22186 & torbernite & 170.6 & 8.0 & Shinkolobwe mine, Shaba, DRC & $\sim 650 \mathrm{Ma}$ & [3] \\
\hline M22186 & torbernite & 167.5 & 1.9 & Shinkolobwe mine, Shaba, DRC & $\sim 650 \mathrm{Ma}$ & [3] \\
\hline M33949 & chervetite & 166.8 & 1.7 & Mounana mine, Gabon & $\sim 2000 \mathrm{Ma}$ & [4] \\
\hline M37121 & mounanaite & 168.0 & 8.2 & Mounana mine, Gabon & $\sim 2000 \mathrm{Ma}$ & [4] \\
\hline M52840 & moctezumite & 436.5 & 27.1 & Moctezuma mine, Sonora, Mexico & $\sim 76$ to $\sim 50 \mathrm{Ma}$ & {$[5]$} \\
\hline M52841 & moctezumite & 502.8 & 46.0 & Moctezuma mine, Sonora, Mexico & $\sim 76$ to $\sim 50 \mathrm{Ma}$ & [5] \\
\hline M52686 & schmitterite & 31.9 & 0.2 & Moctezuma mine, Sonora, Mexico & $\sim 76$ to $\sim 50 \mathrm{Ma}$ & {$[5]$} \\
\hline M52840 & schmitterite & 274.8 & 9.1 & Moctezuma mine, Sonora, Mexico & $\sim 76$ to $\sim 50 \mathrm{Ma}$ & {$[5]$} \\
\hline
\end{tabular}

*Formulae: sklodowskite, $\mathrm{Mg}\left(\mathrm{UO}_{2}\right)_{2}\left(\mathrm{SiO}_{3} \mathrm{OH}\right)_{2} \cdot 6 \mathrm{H}_{2} \mathrm{O}$; parsonsite, $\mathrm{Pb}_{2}\left(\mathrm{UO}_{2}\right)\left(\mathrm{PO}_{4}\right)_{2}$; saléeite, $\mathrm{Mg}\left(\mathrm{UO}_{2}\right)_{2}\left(\mathrm{PO}_{4}\right)_{2} \cdot 10 \mathrm{H}_{2} \mathrm{O}$; dewindtite, $\mathrm{H}_{2} \mathrm{~Pb}_{3}\left(\mathrm{UO}_{2}\right)_{2}\left(\mathrm{PO}_{4}\right)_{4} \mathrm{O}_{4} \cdot 12 \mathrm{H}_{2} \mathrm{O}$; tyuyamunite, $\mathrm{Ca}\left(\mathrm{UO}_{2}\right)_{2}\left(\mathrm{VO}_{4}\right)_{2} \cdot 5-$ $8 \mathrm{H}_{2} \mathrm{O}$; francevillite, $\mathrm{Ba}\left(\mathrm{UO}_{2}\right)_{2}\left(\mathrm{VO}_{4}\right)_{2} \cdot 5 \mathrm{H}_{2} \mathrm{O}$; torbernite, $\mathrm{Cu}\left(\mathrm{UO}_{2}\right)_{2}\left(\mathrm{PO}_{4}\right)_{2} \cdot 12 \mathrm{H}_{2} \mathrm{O}$; chervetite, $\mathrm{Pb}_{2}\left(\mathrm{~V}_{2} \mathrm{O}_{7}\right)$; mounanaite, $\mathrm{PbFe}_{2}\left(\mathrm{VO}_{4}\right)_{2}\left(\mathrm{OH}_{2} \mathrm{~F}\right)_{2} ; \mathrm{moctezumite} \mathrm{Pb}\left(\mathrm{UO}_{2}\right)\left(\mathrm{TeO}_{3}\right)_{2} ; \mathrm{sch}$ itterite, $\left(\mathrm{UO}_{2}\right)\left(\mathrm{TeO}_{3}\right)$. ** Lat/Long: Eva mine: $17^{\circ} 40^{\prime} 48^{\prime \prime} \mathrm{S}, 137^{\circ} 48^{\prime} 36^{\prime \prime} \mathrm{E}$; Ranger mine: $12^{\circ} 41^{\prime} \mathrm{S}, 132^{\circ} 55^{\prime} \mathrm{E}$; Musonoi mine: $10^{\circ} 43^{\prime} 37^{\prime \prime} \mathrm{S}, 25^{\circ} 27^{\prime} 10^{\prime \prime} \mathrm{E}$; Sleisbeck mine: $13^{\circ} 46^{\prime} 51^{\prime \prime} \mathrm{S}, 132^{\circ} 49^{\prime} 36^{\prime \prime} \mathrm{E}$; Shinkolobwe mine: $11^{\circ} 2^{\prime} 54^{\prime \prime} \mathrm{S}$, $26^{\circ} 33^{\prime} 2^{\prime \prime} \mathrm{E}$; Mounana mine: $1^{\circ} 23^{\prime} 54^{\prime \prime} \mathrm{S}, 13^{\circ} 09^{\prime} 09^{\prime \prime} \mathrm{E}$; Moctezuma mine: $29^{\circ} 48^{\prime} \mathrm{N}, 109^{\circ} 40^{\prime} \mathrm{W}$.

References: [1] Hills and Richards (1976); [2] Porada and Berhorst (2000); [3] Decrée et al. (2011); Dewaele et al. (2006); [4] Bonhomme et al. (1982); [5] McDowell et al. (2001).

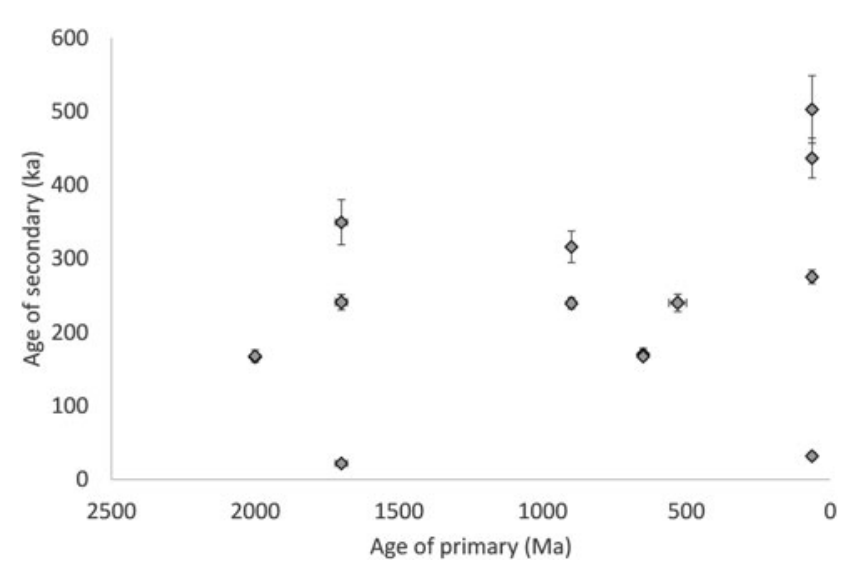

Fig. 2. 'Age' of secondary mineral samples from a variety of worldwide deposits.

high $\mathrm{U}$ concentrations and/or high $\mathrm{U} / \mathrm{Th}$, small splits of each solution were mixed and equilibrated with a ${ }^{233} \mathrm{U}^{229} \mathrm{Th}$ tracer. Given the very small sample sizes, these mixtures could be analysed in the mass spectrometer without further matrix removal by ion exchange. Isotopic analyses were carried out on a $\mathrm{Nu}$ Plasma multi-collector ICP-MS at the University of Melbourne, using a parallel ion-counting method which measures ${ }^{234} \mathrm{U} /{ }^{238} \mathrm{U}$ and ${ }^{230} \mathrm{Th} /{ }^{238} \mathrm{U}$ activity ratios in a single mass-spectrometer run, with full internal calibration of ion counter gains and mass bias (Hellstrom, 2003; Drysdale et al., 2012). A solution of Harwell uraninite (HU-1), assumed to be in secular equilibrium (McCulloch and Esat, 2000), was used to monitor instrument performance and drift, and provide an estimate of external precision. Further details are given in Supplementary Table S1.

\section{Discussion}

We studied samples from a range of geological provinces in the world including those in the Northern Territory, Australia, where the uraninite ages are $\sim 1700$ and $\sim 900 \mathrm{Ma}$; Shaba, Democratic Republic of Congo (560-500 and $650 \mathrm{Ma}$ ); the Moctezuma mines in Sonora, Mexico (76-50 Ma); and the natural fission reactor in Gabon ( $2 \mathrm{Ga})$. While the ages determined for the secondary minerals differ (Table 1 ), they are geologically young for all host deposits $(<503 \mathrm{ka}$; Table 1$)$. These results are consistent with those we obtained in Birch et al. (2011) for samples of saléeite, ulrichite, torbernite and metanatroautunite from the Lake Boga granite (367 Ma, Mills et al., 2008) and Wycheproof granite $(410 \mathrm{Ma})$ in Victoria, Australia. At those localities, 77 of the 104 samples gave apparent ages $<500 \mathrm{ka}$, with a broad peak of $\sim 400 \mathrm{ka}$ (Marine Isotope Stage 11).

We note that a few studies have found pre-Holocene secondary uranium minerals, but none older than late Miocene. Dill et al. (2010) have reported torbernite up to 8.4 Ma occurring in the Bohemian massif of Germany and 1.61 Ma in Galicia, Spain (Dill et al., 2011). These ages are still much younger than their primary $\mathrm{U}$ sources in Variscan granite.

The young ages determined from all of the uranyl minerals that we have examined to date emphasises the fact that these are relatively soluble, reactive species that are easily redissolved over long periods of geological time (Fig. 2). While not ephemeral on the scale of years like many evaporite species, they can be regarded as such on the scale of millions of years. Secondary minerals that formed $2.2 \mathrm{Ga}$ ago will not have been preserved intact through that time, except in the rare instances where they are protected as inclusions in some more refractory phase (e.g. Grew, 2017). The same is true for any oxidised secondary minerals that may have formed earlier. The hydrosphere and atmosphere appear to have transitioned to a consistently oxygenated state only after a few hundred million years of oscillations (Koehler et al., 2018), and there is evidence for locally oxygenated microenvironments as early as $3.46 \mathrm{Ga}$ (Hoashi et al., 2009). Photosynthetic production of oxygen long predated the final catastrophic shift in paradigm, which may have been suppressed while excess reducing species were able to scavenge free oxygen effectively (Catling and Claire, 2005). This is the complementary situation to the present day, where despite the prevalent high oxygen fugacity at the Earth's surface, highly reducing environments still occur but are limited in spatiotemporal extent (Konn et al., 2015).

Secondary minerals may persist for long periods if sufficiently abundant or insoluble. Hematite-stained calcrete horizons define exhumed and cross-sectioned palaeolandscapes of early Palaeozoic age (>350 Ma) on the island of Arran, Scotland (Friend et al., 1970; Young and Caldwell, 2009). Palaeomagnetic data indicate a 
similar age for some Australian regolith environments (Pillans et al., 2004), while other data shows that pisolitic and fragmental duricrust have (U-Th)/He ages of 5.8-1.3 Ma (Wells et al., 2018). Highly insoluble $\mathrm{Mn}^{4+}$ oxide minerals have yielded ages as old as $65 \mathrm{Ma}$ (Vasconcelos et al., 2013). However, most secondary minerals are scarce in quantity and distribution as well as softer than such resistant oxides, and will have crystallised, only to be eradicated later without trace through chemical attack or mechanical erosion.

Such disappearance would be the fate of the very different suite of secondary minerals that would have formed in the anoxic conditions of the early Archaean. These may well have included highly reduced species, which are likely to have been far more common in surficial environments in the Archaean than their rare and ephemeral modern counterparts.

While occurrences of species can certainly be destroyed, it is in fact very difficult to find examples which can be excluded from recurrence elsewhere or in the future. Even when a particular environment is unlikely to recur on Earth, the spatial domain of mineralogy includes other planetary bodies in this Solar System and beyond, in a way that terrestrial biology cannot. High-temperature, Mg-rich komatiitic lavas, and hence any minerals specific to that environment, are almost confined to the Archaean as a result of secular decrease in geothermal gradients. However, a unique much younger (Paleogene) example of a terrestrial komatiite is known (Gansser et al., 1979) and they erupt still on Io, one of the moons of Jupiter (cf. Williams et al., 2000). An even more unusual ancient rock type, the unique Bon Accord nickel oxide-silicate body, is of Archaean age and uncertain paragenesis (Tredoux et al., 2013; O’Driscoll et al., 2014). However, the only two mineral species that are currently found only in this deposit are the relatively oxidised borate bonaccordite, $\mathrm{Ni}_{2} \mathrm{Fe}^{3}$ ${ }^{+}\left[\mathrm{BO}_{3}\right] \mathrm{O}_{2}$ (De Waal et al., 1974) and the antimonate tredouxite, $\mathrm{NiSb}_{2}^{5+} \mathrm{O}_{6}$ (Bindi et al., 2018), which could have been formed by boron metasomatism and oxidation of a $\mathrm{Ni}-\mathrm{Sb}$ sulfide body of any age. Rarity of the physicochemical circumstances required to form a species, and occurrence at only one ancient locality, is likely to provide at most a very temporary form of 'extinct' status.

Given that the species that actually occur are only a subset of those that could do so plausibly (Hazen et al., 2015), there may be many mineral species once present on Earth that are now 'extinct'. Our knowledge of the Earth's former mineralogical inventory is necessarily incomplete, and the apparent secular increase in diversity and complexity may be exaggerated by the loss of species that have long since disappeared. However, while 'virtually all plant and animal species that have ever lived on the earth are extinct' (Raup, 1986), long-absent mineral species may 'return' in the future if favourable conditions recur. This difference in the nature of 'extinction' spotlights the fundamental flaw in the 'evolution' analogy. Phylogenesis of organisms produces unique occurrences of species that are contingent upon the nature of their equally unique predecessors, while paragenesis of minerals lacks this unidirectional, irreversible flow.

Supplementary material. To view supplementary material for this article, please visit https://doi.org/10.1180/mgm.2019.60

Acknowledgements. The Ian Potter Foundation grant 'tracking tellurium' to SJM has funded part of this study. Pierre Clolus is thanked for taking the photomicrographs. Roland Maas (University of Melbourne) is thanked for the sample screening to check $\mathrm{U}-\mathrm{Th}-\mathrm{Pb}$ concentrations and Petra Bajo (University of Melbourne) for running the samples. Frank Hawthorne, Ed Grew, Igor Pekov and Sergey Krivovichev are thanked for their helpful comments.

\section{References}

American Museum of Natural History [AMNH] (2017) American Museum of Natural History to design all-new halls of gems and minerals. Press Release no. 75, October 2017, 6 pp., American Museum of Natural History, New York, USA

Bindi L., Zaccarini F., Miller D.E. and Garuti G. (2018) Tredouxite, $\mathrm{NiSb}_{2} \mathrm{O}_{6}$ : another new Ni-bearing mineral from the Bon Accord oxide body, South Africa. European Journal of Mineralogy, 30, 393-398.

Birch W.D., Mills S.J., Maas R. and Hellstrom J.C. (2011) A chronology for Late Quaternary weathering in the Murray Basin, southeastern Australia: evidence from ${ }^{230} \mathrm{Th} / \mathrm{U}$ dating of secondary uranium phosphates in the Lake Boga and Wycheproof granites, Victoria. Australian Journal of Earth Sciences, 58, 835-845.

Bonhomme M.G., Gauthier-Lafaye F. and Weber F. (1982) An example of Lower Proterozoic sediments: the Francevillian in Gabon. Precambrian Research, 18, 87-102.

Burns P.C., Ewing R.C. and Hawthorne F.C. (1997) The crystal chemistry of hexavalent uranium: polyhedron geometries, bond-valence parameters, and polymerization of polyhedra. The Canadian Mineralogist, 35, 1551-1570.

Catling D.C. and Claire M.W. (2005) How Earth's atmosphere evolved to an oxic state: A status report. Earth and Planetary Science Letters, 237, 1-20.

Decrée S., Deloule É., De Putter T., Dewaele S., Mees F., Yans J. and Marignac C. (2011) SIMS U-Pb dating of uranium mineralization in the Katanga Copperbelt: Constraints for the geodynamic context. Ore Geology Reviews, 40, 81-89.

De Waal S.A., Viljoen E.A. and Calk L.C. (1974) Nickel minerals from Barberton, South Africa: VII. Bonaccordite. The nickel analogue of ludwigite. Transactions of the Geological Society of South Africa, 77, 375.

Dewaele S., Muchez P., Vets J., Fernandez-Alonzo M. and Tack L. (2006) Multiphase origin of the $\mathrm{Cu}-\mathrm{Co}$ ore deposits in the western part of the Lufilian fold-and-thrust belt, Katanga (Democratic Republic of Congo). Journal of African Earth Sciences, 46, 455-469.

Dill H.G., Gerdes A. and Weber B. (2010) Age and mineralogy of supergene uranium minerals-tools to unravel geomorphological and palaeohydrological processes in granitic terrains (Bohemian Massif, SE Germany). Geomorphology, 117, 44-65.

Dill H.G., Gerdes A. and Weber B. (2011) Dating of Pleistocene uranyl phosphates in the supergene alteration zone of Late Variscan granites by Laser-Ablation-Inductive-Coupled-Plasma Mass Spectrometry with a review of $U$ minerals of geochronological relevance to Quaternary geology. Chemie der Erde-Geochemistry, 71, 201-206.

Drysdale R.N., Paul B.T., Hellstrom J., Couchoud I., Greig A., Bajo P., Zanchetta G., Isola I., Spötl C., Baneschi I., Regattieri E. and Woodhead J.D. (2012) Precise microsampling of poorly laminated speleothems for U-series dating. Quaternary Geochronology, 14, 38-47.

Friend P.F., Harland W.B. and Gilbert Smith A. (1970) Reddening and fissuring associated with the Caledonian unconformity in North-West Arran. Proceedings of the Geologists' Association, 81, 75-85.

Gansser A., Dietrich V.J. and Cameron W.E. (1979) Paleogene komatiites from Gorgona Island. Nature, 278, 545-546.

Grew E.S. (2017) Boron: From cosmic scarcity to 300 minerals. Elements, 13, 225-229.

Grew E.S., Krivovichev S.V., Hazen R.M. and Hystad G. (2016) Evolution of structural complexity in boron minerals. The Canadian Mineralogist, 54, $125-143$.

Grew E.S., Hystad G., Toapanta M.P., Eleish A., Ostroverkhova A., Golden J. and Hazen R.M. (2019) Lithium mineral evolution and ecology: comparison with boron and beryllium. European Journal of Mineralogy, https:// doi.org/10.1127/ejm/2019/0031-2862

Hazen R.M. and Eldredge N. (2010) Themes and variations in complex systems. Elements, 6, 43-46.

Hazen R.M., Papineau D., Bleeker W., Downs R.T., Ferry J.M., McCoy T.J., Sverjensky D.A., and Yang H. (2008) Mineral evolution. American Mineralogist, 93, 1693-1720.

Hazen R.M., Ewing R.C. and Sverjensky D.A. (2009) Evolution of uranium and thorium minerals. American Mineralogist, 94, 1293-1311.

Hazen R.M., Golden J., Downs R.T., Hystad G., Grew E.S., Azzolini D., Sverjensky D.A. (2012) Mercury (Hg) mineral evolution: A mineralogical 
record of supercontinent assembly, changing ocean geochemistry, and the emerging terrestrial biosphere. American Mineralogist, 97, 1013-1042.

Hazen R.M., Liu X.-M., Downs R.T., Golden J., Pires A.J., Grew E.S., Hystad G., Estrada C. and Sverjensky D.A. (2014) Mineral evolution: episodic metallogenesis, the supercontinent cycle, and the coevolving geosphere and biosphere. Society of Economic Geologists, Special Publication, 18, 1-15

Hazen R.M., Grew E.S., Downs R.T., Golden J. and Hystad G. (2015) Mineral ecology: chance and necessity in the mineral diversity of terrestrial planets. The Canadian Mineralogist, 53, 295-324.

Hellstrom J. (2003) Rapid and accurate U/Th dating using parallel ion-counting multi-collector ICP-MS, Journal of Analytical Atomic Spectrometry, 18, 1346-1351.

Hills J.H. and Richards J.R. (1976) Pitchblende and galena ages in the Alligator Rivers region, Northern Territory, Australia. Mineralium Deposita, 11, 133-154.

Hoashi M., Bevacqua D.C., Otake T., Watanabe Y., Hickman A.H., Utsunomiya S. and Ohmoto S. (2009) Primary haematite formation in an oxygenated sea 3.46 billion years ago. Nature Geoscience, 2, 301-306.

Koeberl C., Brandstätter F., Harzhauser M. and Riedl-Dorn C. (2018) History and importance of the geoscience collections at the Natural History Museum Vienna. Geological Society of America Special Paper, 535, 131-161.

Koehler M.C., Buick R., Kipp M.A., Stüeken E.E. and Zaloumis J. (2018) Transient surface ocean oxygenation recorded in the $\sim 2.66-\mathrm{Ga}$ Jeerinah Formation, Australia. PNAS, 115, 7711-7716.

Konn C., Charlou J.-C., Holm N.G. and Mousis O. (2015) The production of methane, hydrogen, and organic compounds in ultramafic-hosted hydrothermal vents of the Mid-Atlantic Ridge. Astrobiology, 15, 381-399.

Krivovichev S.V., Krivovichev V.G. and Hazen R.M. (2017) Structural and chemical complexity of minerals: correlations and time evolution. European Journal of Mineralogy, 30, 1-6.

Lussier A.J., Lopez R.A. and Burns P.C. (2016) A revised and expanded structure hierarchy of natural and synthetic hexavalent uranium compounds. The Canadian Mineralogist, 54, 177-283.

McCulloch M.T. and Esat T. (2000) The coral record of last interglacial sea levels and sea surface temperatures. Chemical Geology, 169, 107-129.

McDowell F.W., Roldán-Quintana J. and Connelly J.N. (2001) Duration of Late Cretaceous-early Tertiary magmatism in east-central Sonora, Mexico. Geological Society of America Bulletin, 113, 521-531.

Mills S.J., Birch W.D., Maas R., Phillips D. and Plimer I.R. (2008) Lake Boga Granite, northwestern Victoria: mineralogy, geochemistry and geochronology. Australian Journal of Earth Sciences, 55, 281-299.
Newman M.E.J. (1997) A model for mass extinction. Journal of theoretical Biology, 189, 235-252.

O’Driscoll B., Clay P.L., Cawthorn R.G., Lenaz D., Adetunji J. and Kronz A. (2014) Trevorite: Ni-rich spinel formed by metasomatism and desulfurization processes at Bon Accord, South Africa? Mineralogical Magazine, 78, 145-163.

Porada H. and Berhorst V. (2000) Towards a new understanding of the Neoproterozoic-Early Palaeozoic Lufilian and northern Zambezi Belts in Zambia and the Democratic Republic of Congo. Journal of African Earth Sciences, 30, 727-771.

Pillans B., Tonui E. and Idnurm M. (2004) Paleomagnetic dating of weathered regolith at Northparkes mine, NSW. Pp. 237-242 in: New Approaches to an Old Continent (G. Taylor and C. Pain, editors). Cooperative Research Centre for Landscape Evolution and Mineral Exploration, Perth, Australia.

Raup D.M. (1986) Biological extinction in Earth history. Science, 231, 1528-1533.

Stewart J.A. (2014) The direction of evolution: the rise of cooperative organization. Biosystems, 123, 27-36.

Tredoux M., Roelofse F. and Shukolyukov A. (2013) A Cr isotopic study of the Bon Accord NiO body in the Barberton greenstone belt, South Africa. Chemical Geology, 390, 182-190

Vasconcelos C. and McKenzie J.A. (2009) The Descent of Minerals. Science, 323, 218-219.

Vasconcelos P.M., Heim J.A., Farley J.A., Monteiro H. and Waltenberg K. (2013) Ar-40/Ar-39 and (U-Th)/He-He-4/He-3 geochronology of landscape evolution and channel iron deposit genesis at Lynn Peak, Western Australia. Geochimica et Cosmochimica Acta, 117, 283-312.

Wells M., Danišík M., McInnes B. and Morris P. (2018) Miocene-Pliocene (U$\mathrm{Th}) / \mathrm{He}$ ages for lateritic duricrust, in the southwest Darling Range, WA. XXII General Meeting of the International Mineralogical Association Melbourne, Australia, August 2018, p. 188.

Williams D.A., Wilson A.H. and Greeley R. (2000) A komatiite analog to potential ultramafic materials on Io. Journal of Geophysical Research, 105, 1671-1684.

Young G.M. and Caldwell W.G.E. (2009) A new look at an old unconformity: field and geochemical data from James Hutton's original unconformity on the Isle of Arran, Scotland. Proceedings of the Geologists' Association, 120, 65-75.

Zhabin A.G. (1979) Is there evolution of mineral speciation on Earth? Doklady Akademii Nauk, 247, 199-202 [in Russian; translation: Doklady Earth Science Sections, 247, 142-144]. 